\title{
61. LOW TEMPERATURE ALTERATION OF OCEANIC BASALTS, DSDP LEG 37
}

\author{
Paul T. Robinson, Department of Earth Sciences, University of California, Riverside, California, \\ Martin F.J. Flower,' Hans-Ulrich Schminke, and Walter Ohnmacht, \\ Institut für Mineralogie, Ruhr Universität-Bochum, Bochum, West Germany
}

\section{INTRODUCTION}

During Leg 37 deep penetration of acoustic basement was achieved at four sites on the west flank of the MidAtlantic Ridge at approximately $37^{\circ} \mathrm{N}$ latitude. These sites $(332,333,334$, and 335$)$ were drilled along a seafloor-spreading flow line in rocks ranging in age from about 3.5 to $13 \mathrm{~m} . \mathrm{y}$. The maximum subbasement penetration $(583 \mathrm{~m})$ was achieved at Hole $332 \mathrm{~B}$; depth of penetration at the other holes ranged from about 180 to 330 meters. These holes provide an excellent opportunity to investigate the nature and intensity of alteration of sea-floor basalts in relation to lithology, age, and depth within layer 2 of the ocean crust.

Previous studies of alteration of sea-floor basalts, dealing mainly with dredged samples, have shown that alteration is due largely to low temperature chemical interchange between seawater and rock or magma. This type of alteration is most pronounced along fractures and open channelways and involves the growth of smectite, carbonate, and phillipsite. The resulting chemical changes, as recently summarized by Scott and Hajash (1976), generally involve notable increases in $\mathrm{H}_{2} \mathrm{O}, \mathrm{Fe}_{2} \mathrm{O}_{3}, \mathrm{~K}_{2} \mathrm{O}, \mathrm{Rb}, \mathrm{Cs}, \mathrm{U}$ and smaller increases in total iron, $\mathrm{B}, \mathrm{Ce}, \mathrm{Sr}, \mathrm{V}, \mathrm{Zr}$, and $\mathrm{Pb}$. $\mathrm{TiO}_{2}$ and $\mathrm{P}_{2} \mathrm{O}_{5}$ are generally considered to be little affected by low temperature alteration, but small increases in these oxides have been noted by Hart (1970), Miyashiro et al. (1969), Melson (1973), and Shido et al. (1974). Several workers have noted increasing alteration with age of the sea floor (Hart, 1970; Aumento, 1971).

Recently extensive hydrothermal circulation and alteration in layer 2 has been postulated to explain the anomalously low and scattered heat-flow values observed over spreading ridges (Lister, 1972; Anderson, 1972). The secondary mineral assemblages and chemical changes produced by hydrothermal alteration of basalts are distinctly different from those produced by low temperature alteration. Epidote, prehnite, albite, and wairakite are characteristic hydrothermal minerals in altered basalts, and growth of these minerals is accompanied by loss of $\mathrm{CaO}, \mathrm{K}_{2} \mathrm{O}$, and $\mathrm{SiO}_{2}$ and gain of $\mathrm{MgO}$ and $\mathrm{SO}_{4}$ (Tómassen and Kristmannsdóttir, 1972).

\section{ALTERATION PROCESSES IN LEG 37 BASALTS}

Alteration of Leg 37 basalts involved oxidation, hydration, and the growth of secondary minerals at

\footnotetext{
'Permanent address: Department of Earth Sciences, University of California, Riverside, California.
}

temperatures close to ambient seawater. Two modes of occurrence are apparent. The most intense alteration is in bands or halos extending outward from fractures or veinlets. Many of these channelways are filled with nannofossil ooze or chalk indicating the direct introduction of seawater along the fractures. The rocks in these halos are strongly oxidized, being various shades of yellow and red, and they contain abundant carbonate, smectite, and zeolite. The altered zones are typically 10 to 20 times the width of the associated fracture and may range up to 30 times or more. Hence, where fractures are closely spaced, the entire rock is highly altered; elsewhere, the altered and less altered zones are separated by very sharp diffusion-controlled color boundaries.

Many rocks exhibit a lower grade, pervasive nonoxidative alteration, spatially unrelated to open channelways. This type of alteration involves chiefly the replacement of olivine and interstitial groundmass material by smectite without noticeable oxidation. Vesicles are open or lined with light blue or brown smectite and minor carbonate.

Secondary minerals in Leg 37 basalts occur chiefly in fractures and vesicles, or replacing interstitial groundmass material. Olivine is often partly to completely replaced by mixtures of smectite, carbonate, iron oxide, or silica, but other primary minerals are rarely affected. A few plagioclase phenocrysts, cut by veinlets of carbonate and phillipsite, exhibit minor replacement by these minerals along cleavage traces. Alteration of pyroxene was not observed.

\section{SECONDARY MINERALS IN LEG 37 BASALTS}

Clay minerals, carbonates, and zeolites are the most common and abundant secondary minerals in Leg 37 basalts, but many others occur in small quantities (Table 1). Identification of secondary minerals is based on optical data, X-ray diffraction analyses, and electron microprobe analyses. Microprobe analysis of secondary minerals poses special problems because of small grain size, high volatile content, and mineral inhomogeneity. For most analyses reported here the electron beam was defocused to $40 \mu \mathrm{m}$ to reduce decomposition of the minerals. Even with a defocused beam, however, zeolites, sulfates, and some carbonates exhibit severe decomposition. In addition, many of the secondary minerals could not be evenly polished, thus introducing an additional source of analytical uncertainty. Despite these problems, however, the analyses reported here show a high degree of uniformity and repeatability and, except where noted, are believed to be satisfactory. 
TABLE 1

Occurrence of Secondary Minerals in Leg 37 Basalts

\begin{tabular}{lcccc}
\hline \multicolumn{1}{c}{ Mineral } & Vesicles & $\begin{array}{c}\text { Veins } \\
\text { and Vugs }\end{array}$ & $\begin{array}{c}\text { Basalt } \\
\text { Groundmass }\end{array}$ & $\begin{array}{c}\text { Phenocryst } \\
\text { Replacement }\end{array}$ \\
\hline Brown smectite $^{\mathrm{a}, \mathrm{b}}$ & $\mathrm{X}$ & & $\mathrm{X}$ & $\mathrm{X}$ \\
Yellow smectite $^{\mathrm{a}, \mathrm{b}}$ & $\mathrm{X}$ & $\mathrm{X}$ & $\mathrm{X}$ & $\mathrm{X}$ \\
Red smectite $^{\mathrm{b}}$ & $\mathrm{X}$ & $\mathrm{X}$ & $\mathrm{X}$ & $\mathrm{X}$ \\
Calcite $^{\mathrm{a}}$ & $\mathrm{X}$ & $\mathrm{X}$ & $\mathrm{X}$ & $\mathrm{X}$ \\
Aragonite $^{\mathrm{a}}$ & $\mathrm{X}$ & $\mathrm{X}$ & & \\
Dolomite $^{\mathrm{a}, \mathrm{b}}$ & $\mathrm{X}$ & $\mathrm{X}$ & & \\
Magnesite $^{\mathrm{a}, \mathrm{b}}$ & $\mathrm{X}$ & & & \\
Sulfate $^{\mathrm{b}}$ & $\mathrm{X}$ & $\mathrm{X}$ & & $\mathrm{X}$ \\
Opal $^{\mathrm{b}}$ & $\mathrm{X}$ & & & \\
PHillipsite $^{\mathrm{a}, \mathrm{b}}$ & $\mathrm{X}$ & $\mathrm{X}$ & & $\mathrm{X}$ \\
Leucoxene $^{\mathrm{b}}$ & $\mathrm{X}$ & $\mathrm{X}$ & & \\
Pyrite $^{\text {Manganese hydroxide }}$ & $\mathrm{X}$ & $\mathrm{X}$ & & \\
Iron hydroxide $^{\mathrm{b}}$ & & & & \\
\hline
\end{tabular}

adentification by $\mathrm{X}$-ray diffraction analysis.

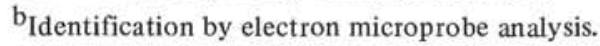

\section{Clay Minerals}

Clay minerals are present in nearly all Leg 37 basalts and some specimens contain up to 15 modal percent. The clay minerals most commonly occur lining or filling vesicles and veinlets or replacing olivine and interstitial groundmass material. In some specimens the clay minerals are uniformly distributed; in others they occur in well-defined alteration halos surrounding fractures and veinlets.

All of the clay minerals investigated are smectites, i.e., they have a basal spacing of approximately $14 \AA$ which expands to 17 or $18 \AA$ after solvation with glycol. Upon heating, the basal spacing collapses to $10 \AA$ or less. Optically, the smectites consist of fine-grained platey or fibrous crystals with moderate to high birefringence. The crystals are commonly oriented normal to the walls of vesicles and veinlets, suggesting growth into open space.

The major optical variation is color. Most smectites are light brown or yellow in thin section; others are green, red, or black. A few specimens contain small quantities of yellow, isotropic, material identified optically as chlorophaeite.

The most widespread and abundant smectite is a light blue to bluish-gray variety which is colorless to light brown in thin section. This variety lines and fills vesicles and replaces interstitial groundmass material and olivine (Plate 1, Figures 2, 3). It is normally distributed uniformly through a given lithologic unit and is not found in fractures or veins.

Many vesicle fillings exhibit distinct smectite layers suggesting different depositional episodes. A typical sequence consists of an outermost layer of variable thickness composed of light brown, well-crystallized birefringent material. This is followed by a thin layer of very fine grained pale greenish-brown smectite which in turn is followed by light brown material that is well crystallized at the outer edge, but becomes progressive- ly finer grained toward the center of the vesicle. Around the central core, which may be open or filled with phillipsite or carbonate, the pale brown smectite is often stained a dark brown. Some specimens exhibit a reverse zonation in the vesicles, with an outer rim of fine-grained, light colored material which grades into a core filled with rosettes of coarser, euhedral dark brown crystals.

Green smectite occurs chiefly in the lower part of Hole 332B, where it lines fractures and fills veinlets. On fracture surfaces this material has a deep green, waxy appearance and is sometimes associated with pyrite and minor carbonate. In most specimens, the green smectite is confined to the fractures but in some cases green and brown smectite are both present in the vesicles. Where this occurs the green smectite normally forms a thin outer layer on the vesicle wall followed by abundant brown material.

Yellow and red smectites always occur in alteration halos along fractures and veinlets and are related to the passage of oxidizing fluids through the rock. Where brown or green smectite was already present, it was stained and altered by the oxidizing fluids. In these cases the vesicles in front of the oxidation halo are filled with brown smectite and a sharp color boundary separates the oxidized and unoxidized material. Elsewhere the modal percent of smectite is directly related to the alteration halo. In front of the halo, vesicles are empty or partly filled with carbonate whereas behind the boundary yellow or red smectite is abundant.

Microprobe analyses of the smectites reveal two major compositional groups (Table 2). The colorless to light brown varieties are characterized by high $\mathrm{MgO}$ (21-26 wt\%), low total iron (5-8 wt\%), and very low $\mathrm{K}_{2} \mathrm{O}(0.02-0.34 \mathrm{wt} \%)$. Both $\mathrm{SiO}_{2}$ and $\mathrm{Al}_{2} \mathrm{O}_{3}$ vary widely, but these oxides exhibit a marked negative correlation and the combined total of the two remains nearly constant (52-55 wt\%). Oxide totals are uniform but rela- 
TABLE 2

Defocused Electron Probe Analyses of Birefringent Clay Minerals

\begin{tabular}{|c|c|c|c|c|c|c|c|c|c|c|c|c|c|c|}
\hline & 1 & 2 & 3 & 4 & 5 & 6 & 7 & 8 & 9 & 10 & 11 & 12 & 13 & 14 \\
\hline $\mathrm{SiO}_{2}$ & 43.61 & 49.80 & 54.57 & 46.99 & 41.52 & 49.44 & 46.76 & 49.03 & 51.75 & 45.96 & 46.27 & 48.41 & 49.82 & 46.17 \\
\hline $\mathrm{TiO}_{2}$ & 0.02 & 0.02 & 0.01 & tr. & - & 0.01 & 0.03 & 0.02 & 0.10 & - & 0.03 & 0.02 & 0.01 & - \\
\hline $\mathrm{Al}_{2} \mathrm{O}_{3}$ & 9.19 & 3.44 & 0.53 & 5.09 & 12.66 & 2.85 & 3.53 & 0.93 & 4.77 & 4.23 & 3.35 & 0.93 & 0.15 & 4.58 \\
\hline $\mathrm{FeO}^{*}$ & 8.35 & 8.80 & 5.81 & 5.80 & 5.33 & 28.24 & 29.34 & 32.57 & 30.62 & 26.93 & 33.32 & 33.66 & 31.39 & 27.73 \\
\hline $\mathrm{MnO}$ & 0.05 & 0.04 & 0.02 & 0.01 & 0.13 & 0.12 & 0.18 & - & 0.02 & 0.02 & 0.07 & 0.05 & 0.02 & 0.06 \\
\hline $\mathrm{MgO}$ & 23.58 & 21.37 & 24.62 & 24.08 & 25.96 & 5.10 & 4.10 & 4.20 & 2.72 & 8.07 & 3.27 & 4.23 & 4.78 & 4.69 \\
\hline $\mathrm{CaO}$ & 0.81 & 0.47 & 0.20 & 0.79 & 1.00 & 0.48 & 1.00 & 0.39 & 0.22 & 1.25 & 0.39 & 0.87 & 0.78 & 0.59 \\
\hline $\mathrm{Na}_{2} \mathrm{O}$ & 0.08 & 0.11 & 0.12 & 0.12 & 0.09 & 0.29 & 0.21 & 0.13 & 0.06 & 0.08 & 0.78 & 0.12 & 0.05 & 0.26 \\
\hline $\mathrm{K}_{2} \mathrm{O}$ & 0.13 & 0.29 & 0.34 & 0.15 & 0.02 & 5.88 & 6.03 & 5.68 & 5.18 & 4.13 & 5.68 & 3.79 & 3.85 & 5.37 \\
\hline $\mathrm{ZnO}$ & 0.18 & - & 0.02 & 0.14 & n.d. & 0.08 & 0.02 & 0.01 & 0.08 & 0.20 & 0.06 & 0.04 & 0.16 & - \\
\hline $\mathrm{F}$ & 0.06 & 0.03 & 0.05 & 0.10 & n.d. & 0.10 & 0.12 & - & - & 0.03 & - & - & - & 0.05 \\
\hline $\mathrm{Cl}$ & 0.03 & 0.06 & 0.04 & 0.05 & n.d. & 0.03 & 0.74 & 0.02 & 0.05 & tr. & 0.07 & 0.02 & 0.01 & 0.03 \\
\hline Total & 86.09 & 84.43 & 86.33 & 83.32 & 86.71 & 92.62 & 92.06 & 92.98 & 95.57 & 90.90 & 93.29 & 91.63 & 91.02 & 89.53 \\
\hline
\end{tabular}

Note: $\mathrm{FeO}^{*}=$ total iron, $\mathrm{n} . \mathrm{d} .=$ not determined; $-=$ oxide below detection level. 1 = Light brown smectite lining vesicles $(332 \mathrm{~B}-2-6,90-93 \mathrm{~cm}) ; 2$ = Light brown smectite replacing olivine microphenocryst $(332 \mathrm{~B}-8-3,90 \mathrm{~cm}) ; 3=$ Light brown smectite filling vesicles $(332 \mathrm{~B}-8-3,90 \mathrm{~cm}) ; 4=\mathrm{Light}$ brown smectite filling vesicles (332B-2-6, 94-97 cm); $5=$ Colorless to pale brown smectite filling center of vesicle lined with yellow and red smectite $(332 \mathrm{~B}-42-2,26-28 \mathrm{~cm}) ; 6$ = Golden brown smectite lining vesicles (332A-17-1, 50-52 cm); $7=$ Golden brown smectite lining vesicles $(332 \mathrm{~A}-17-$ $1,50-52 \mathrm{~cm}) ; 8=$ Yellow smectite lining vesicles $(332 \mathrm{~B}-8-1,12 \mathrm{~cm}) ; 9=$ Yellow smectite replacing groundmass olivine $(332 \mathrm{~B}-33-1,5-8 \mathrm{~cm}) ; 10=$ Yellow smectite lining vesicles filled with light brown smectite $(332 \mathrm{~B}-42-2,26-28 \mathrm{~cm}) ; 11=$ Yellow smectite coated with iron oxide on vesicle wall $(332 \mathrm{~A}-26-1,102 \mathrm{~cm}) ; 12=$ Light yellow smectite on vesicle wall $(332 \mathrm{~A}-6-2,122 \mathrm{~cm}) ; 13=$ Light yellow smectite filling vesicles $(332 \mathrm{~B}-6-2,122 \mathrm{~cm})$; 14 = Red smectite filling vesicles (332B-40-1, 20-22 cm).

tively low, suggesting up to $17 \mathrm{wt} \% \mathrm{H}_{2} \mathrm{O}$ in interlayer positions.

Yellow and red smectites comprise a high iron-high $\mathrm{K}_{2} \mathrm{O}$ group similar to smectites previously reported from sea-floor basalts (e.g., Melson and Thompson, 1973). Iron normally varies between about 28 and 34 wt\%; a few red smectites with higher iron contents and very low $\mathrm{SiO}_{2}$ probably represent mixtures of clay minerals and hematite. $\mathrm{K}_{2} \mathrm{O}$ is markedly enriched compared to the brown smectites, averaging about $5 \mathrm{wt} \%$, and $\mathrm{MgO}$ is markedly depleted (2.5-8.0 wt\%). $\mathrm{Al}_{2} \mathrm{O}_{3}$ is variable, again showing a negative correlation with $\mathrm{SiO}_{2}$; however, the average is only about one-half that of the brown smectites. Oxide totals are consistently higher indicating less interlayer $\mathrm{H}_{2} \mathrm{O}$.

Compositional variations within the two groups cannot be correlated with mode of occurrence of the smectite, i.e., whether it occurs as vesicle fillings or as replacement of olivine or interstitial groundmass material. However, in many vesicles the smectites exhibit a distinct color and compositional zonation. The most common arrangement is an outer layer of brown or green smectite which grades inward through shades of yellow to a bright golden orange or red layer. Across a sharp boundary, the red layer is often followed by light brown to colorless, or rarely black, material in the vesicle core (Plate 2, Figure 1). Table 3 gives the compositional variations associated with one such vesicle. Here the outermost material is a greenish-yellow, high $\mathrm{FeO}$-high $\mathrm{K}_{2} \mathrm{O}$ smectite. The red layer is very rich in $\mathrm{FeO}$ and low in $\mathrm{SiO}_{2}$ and may represent a mixture of smectite and hematite. The innermost brown smectite is low in $\mathrm{K}_{2} \mathrm{O}$ and high in $\mathrm{MgO}$ similar to brown varieties elsewhere. All of the zoned vesicles are located in oxidation halos along veins and fractures, and the observed
TABLE 3

Compositional Variations of Smectites in a Zoned Vesicle (332B-42-2, 26- $28 \mathrm{~cm}$ ).

\begin{tabular}{|c|c|c|c|}
\hline & 1 & 2 & 3 \\
\hline $\mathrm{SiO}_{2}$ & 44.59 & 27.68 & 41.52 \\
\hline $\mathrm{TiO}_{2}$ & - & $\operatorname{tr}$ & - \\
\hline $\mathrm{Al}_{2} \mathrm{O}_{3}$ & 4.40 & 3.09 & 12.66 \\
\hline $\mathrm{FeO}$ & 27.65 & 45.98 & 5.33 \\
\hline $\mathrm{MnO}$ & 0.01 & 0.13 & 0.13 \\
\hline $\mathrm{MgO}$ & 8.03 & 5.83 & 25.96 \\
\hline $\mathrm{CaO}$ & 1.20 & 1.18 & 1.00 \\
\hline $\mathrm{Na}_{2} \mathrm{O}$ & 0.09 & 0.06 & 0.09 \\
\hline $\mathrm{K}_{2} \mathrm{O}$ & 3.92 & 0.19 & 0.02 \\
\hline Total & 89.89 & 84.14 & 86.71 \\
\hline
\end{tabular}

\footnotetext{
Note: $\mathrm{FeO}=$ total iron; $\mathrm{tr}=$ trace; _ = not detected; 1 = Greenishyellow smectite lining vesicle wall; $2=$ Red smectite rimming layer of yellow smectite; $3=$ Light brown smectite filling center of vesicle.
}

chemical variations presumably reflect changes in the composition of the fluids moving through the rock. The gradation from greenish-yellow to yellow to red smectite suggests deposition under conditions of gradually increasing oxidation. A sharp change in fluid composition is indicated by the change from red to light brown smectite in the core, reflecting a sharp decrease in $\mathrm{FeO}$ and $\mathrm{K}_{2} \mathrm{O}$ and an increase in $\mathrm{MgO}$ and $\mathrm{Al}_{2} \mathrm{O}_{3}$. It is possible that this sharp compositional boundary may coincide with closing of the associated vein or fracture by precipitation of secondary minerals. 


\section{Carbonates}

Secondary carbonates are widespread and abundant in Leg 37 basalts, being second in importance only to clay minerals. They occur in vesicles, veins, and vugs and as replacements of phenocrysts and groundmass material. The carbonates are irregularly distributed being most abundant in oxidation halos where the rock is highly fractured. One interval in the lower part of Hole $332 \mathrm{~B}$ is extraordinarily rich in carbonate with some specimens having more than $6 \mathrm{wt} \% \mathrm{CO}_{2}$ (Figure $1 \mathrm{~b}$ ).

Four distinct carbonate minerals-calcite, aragonite, dolomite, and magnesite-have been identified by X-ray diffraction studies. Calcite is the most common and widespread variety, occurring in small quantities in nearly all specimens examined. In vesicles it forms small hemispheres with radial textures attached to the vesicle walls (Plate 1, Figure 4). These hemispheres often occur singly or several may coalesce to fill the entire cavity. Most fractures and veins are filled with polycrystalline sparry calcite or with radial hemispheres similar to those in vesicles. In the latter case, the calcite has a pronounced botryoidal habit on fracture surfaces and vug walls (Plate 1, Figure 6). Near pillow margins the veins and fractures are often filled with nannofossil ooze or chalk, generally with a thin layer of sparry calcite between the chalk and the vein well. Clay minerals and phillipsite often line the walls of calcite-filled vesicles and veins.

Calcite also commonly replaces olivine phenocrysts with or without clay minerals, iron oxides, or silica. Some plagioclase phenocrysts cut by calcite veins exhibit minor replacement along cleavage traces but are otherwise unaltered. In the groundmass calcite fills small irregularly shaped cavities and replaces olivine and poorly crystallized interstitial material.

Aragonite has been found only in calcite-lined vugs where it forms clear, prismatic crystals up to $5 \mathrm{~mm}$ long. It is not widely distributed.

Dolomite and magnesite occur almost exclusively in the carbonate-rich interval in Hole 332B. This interval, between 500 and 610 meters subbottom, consists chiefly of olivine phyric basalts of lithologic units 6 and 7 . The rocks are cut by numerous closely spaced fractures and are highly altered. Olivine phenocrysts are replaced by mixtures of carbonate and silica and abundant carbonate fills vesicles and replaces groundmass material.

The magnesian carbonates are optically similar to calcite except for a faint brownish color in thin section. Like calcite they form spheres and hemispheres in vesicles and vugs (Plate 1, Figure 5). The spheres normally have a radial fibrous structure and are characterized by pronounced concentric compositional zoning reflecting variations in $\mathrm{CaO}, \mathrm{MgO}$, and $\mathrm{FeO}$. Where calcite is also present it usually precedes the dolomite and magnesite (Plate 1, Figure 6).

Microprobe analyses of the carbonates show a wide range of chemical composition with extensive solid solution (Table 4). Oxide totals are consistently low, suggesting either hydration of the carbonates or, more likely, analytical error. Most of the carbonates are finegrained, polycrystalline aggregates which are difficult to polish, and individual crystals are generally smaller than the electron beam. Even though a defocused beam was used during analysis, most of the carbonates were severely burned suggesting loss of $\mathrm{CO}_{2}$. However, despite the low totals, the relative proportions of $\mathrm{CaO}$, $\mathrm{MgO}$, and $\mathrm{FeO}$ should be correct.

Compositionally, the carbonates fall into three main groups based on $\mathrm{CaO}$ content; calcite, dolomite, and low calcium, iron-magnesian carbonates (Table 4). The calcite and dolomite are relatively uniform in composition although some solid solution is suggested. The iron-magnesian carbonates, on the other hand, are highly variable, with $\mathrm{CaO}$ ranging from 5 to $19 \mathrm{wt} \%$, $\mathrm{FeO}$ from 14 to $35 \mathrm{wt} \%$, and $\mathrm{MgO}$ from 7 to $30 \mathrm{wt} \%$. Compositionally, these carbonates range from calciumand iron-rich magnesite to iron-rich huntite to calciumand magnesium-rich siderite. However, only dolomite and magnesite have been recognized in X-ray diffraction patterns. The compositional variations reflect zoning within single carbonate spheres, each type representing a single discrete layer (Table 5).

The origin of the iron-magnesian carbonates is uncertain. These minerals occur only in highly fractured rock with many open channelways suggesting introduction of the carbonate from seawater. On the other hand, the host rocks are highly altered olivine-phyric basalts and picrites, and the iron and magnesium may have been released by the breakdown of olivine.

The presence of abundant secondary iron-magnesian carbonates in Leg 37 basalts indicates that $\mathrm{FeO}$ and $\mathrm{MgO}$ can be quite mobile during alteration. $\mathrm{CO}_{2}$ corrections of whole-rock analyses based only on calcite will produce misleading results wherever such carbonates are present.

\section{Zeolites}

Phillipsite is the only zeolite positively identified in Leg 37 basalts. Isotropic material tentatively identified optically by the shipboard party as analcime is opal.

Phillipsite is widely distributed, occurring most commonly in fractures and veinlets and in palagonite breccias at pillow margins. It also occurs in vesicles close to or connected with open channelways.

The phillipsite typically forms clusters of radiating prismatic crystals from 0.1 to $0.33 \mathrm{~mm}$ long lining fracture walls (Plate 2, Figure 2). In a few specimens individual crystals are too small to be distinguished optically and in one specimen single crystals exceed 0.5 $\mathrm{mm}$ in length (Plate 2, Figure 3). The radiating clusters are oriented normal to the fracture wall suggesting growth into open space. The central part of the cavity may be open or partly filled with carbonate, yellow smectite, or randomly oriented phillipsite crystals. In palagonite breccias the phillipsite is associated with sparry calcite and fills fractures between glass fragments and the enclosing nannofossil chalk. In a few specimens it fills vesicles or other cavities in the breccias, but it has not been observed replacing glass.

The distribution and the mode of occurrence of phillipsite indicate that it precipitated from seawater solutions along fractures and open channelways. Microprobe analyses are given in Table 6.

\section{Opaque Minerals}

Secondary opaque minerals include pyrite, leucoxene, manganese coatings, and hematite. Only pyrite is abundant and widely distributed. 


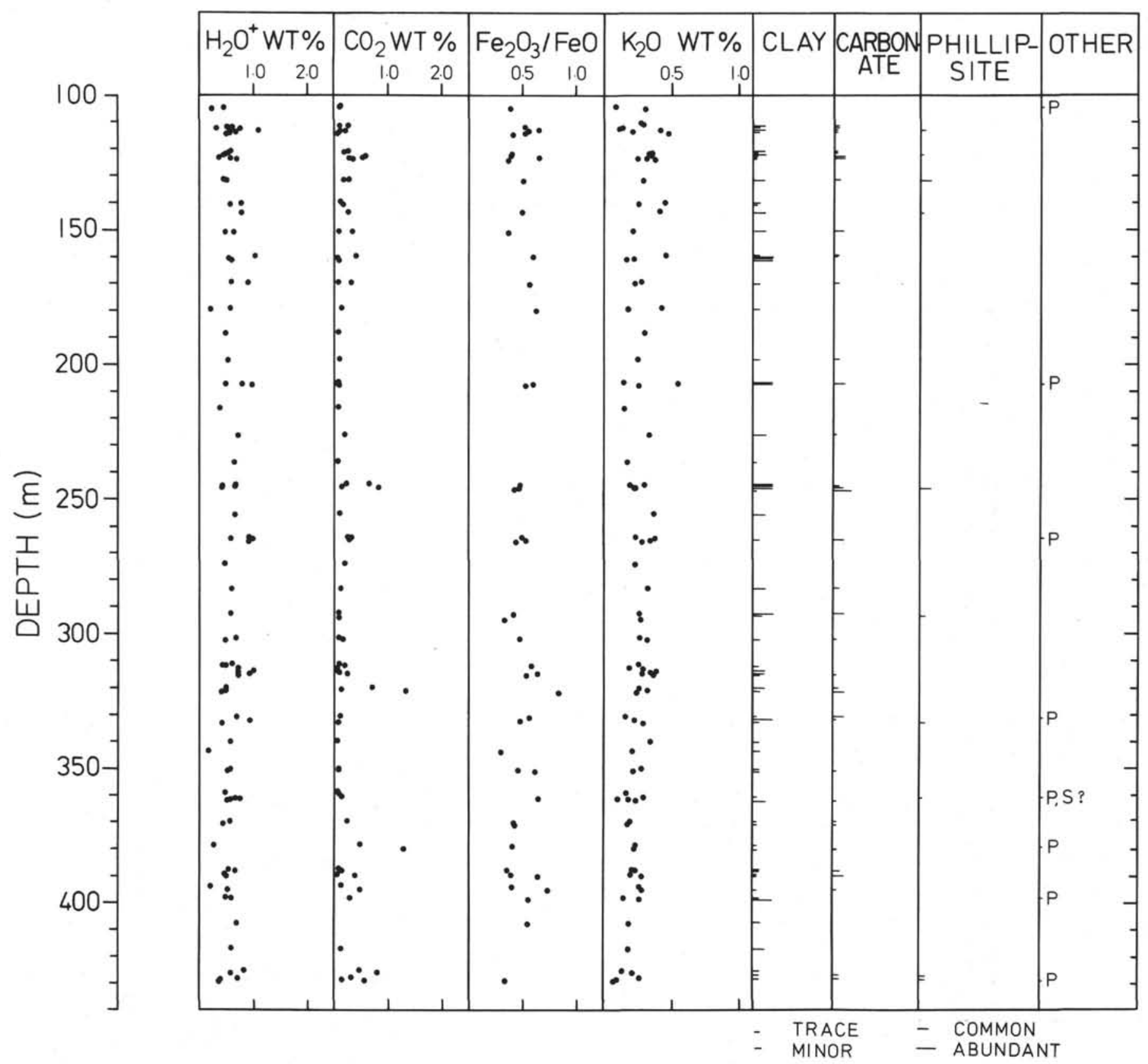

Figure 1a. Downhole variations in $\mathrm{H}_{2} \mathrm{O}^{+}, \mathrm{CO}_{2}, \mathrm{~K}_{2} \mathrm{O}, \mathrm{Fe}_{2} \mathrm{O}_{3} / \mathrm{FeO}$ ratios and various secondary minerals in Hole 332A. Figure includes shipboard chemical data and shore-based chemical and mineralogical data produced by us. Symbols are as follows: $P=$ pyrite, $A=$ analcime (?), $S=$ silica, $S u=$ sulfate mineral.

\section{Pyrite}

Shipboard examination of polished sections suggested that both primary and secondary sulfides are present in Leg 37 basalts. The present study is concerned only with those sulfides that are clearly secondary in origin, i.e., those associated with other secondary minerals in veins and vesicles. These sulfides are primarily, if not exclusively, pyrite.

In vesicles pyrite typically forms spherical framboids composed of many tiny cubes packed randomly together. One or more spheres may be attached to the vesicle wall and in some cases these coalesce to fill the entire cavity. The vesicle walls are always coated with green or brown smectite that preceded the pyrite, and normally the framboids are attached to the walls at a single point. The origin of the framboids is unknown; however, similar forms in sedimentary rocks have been interpreted as being the result of diagenetic reduction of sulfate minerals by microorganisms in an anaerobic environment (Love, 1964). Sulfate minerals are locally present in vesicles in Leg 37 basalts, often in close proximity to pyrite framboids, but no clear relationship between the two has been established.

In veins and fractures pyrite most commonly occurs as fine-grained crusts or as individual cubes up to onehalf $\mathrm{mm}$ across. Here the pyrite is associated with green smectite or carbonate, or both. Where smectite is pres- 


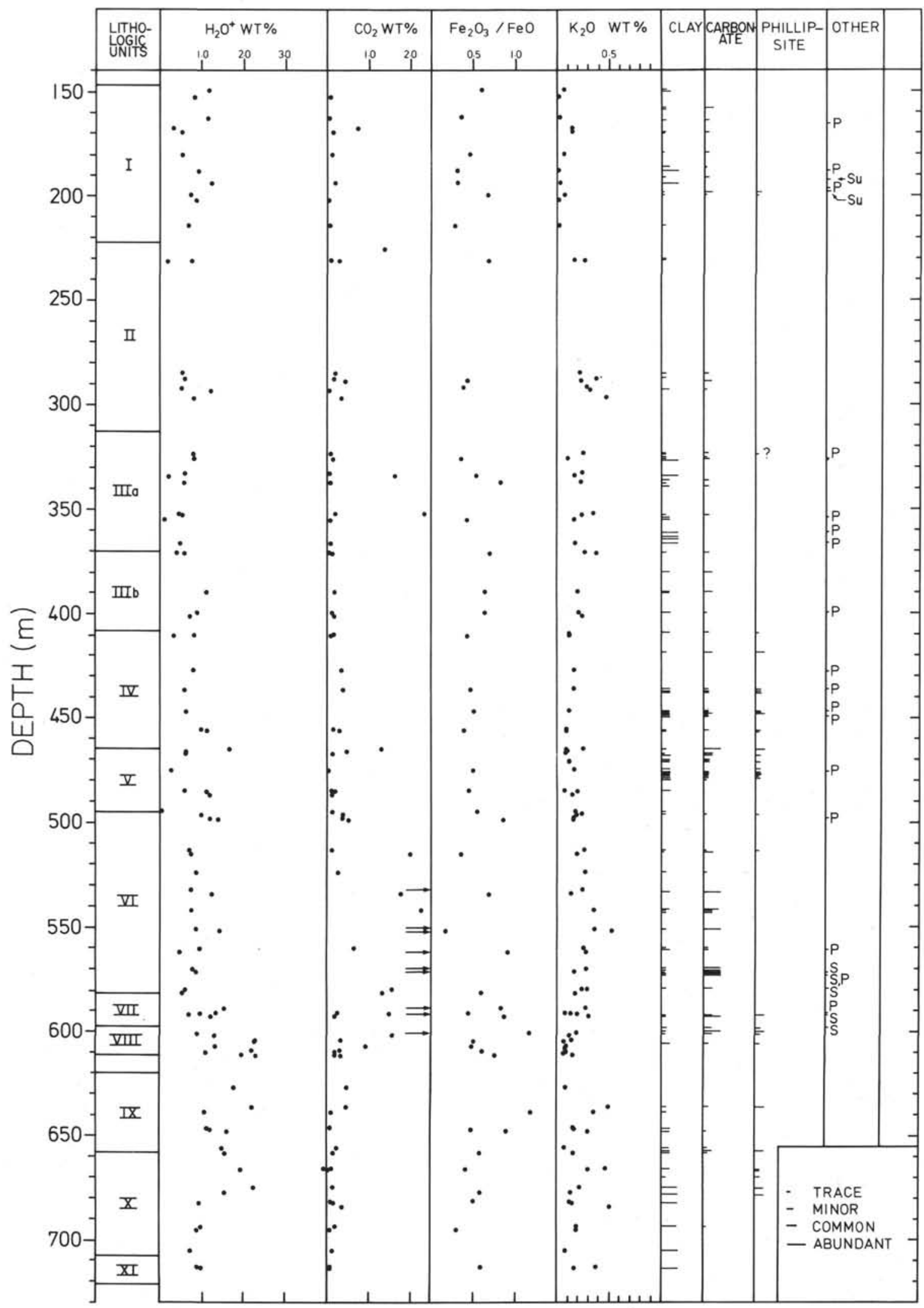

Figure 1b. Downhole variations in $\mathrm{H}_{2} \mathrm{O}^{+}, \mathrm{CO}_{2}, \mathrm{~K}_{2} \mathrm{O}, \mathrm{Fe}_{2} \mathrm{O}_{3} / \mathrm{FeO}$ ratios and various secondary minerals, Hole 332B. Figure includes shipboard chemical data and shore-based chemical and mineralogical data produced by us. Symbols are as follows: $P=$ pyrite, $A=$ analcime (?), $S=$ silica, $S u=$ sulfate mineral. 


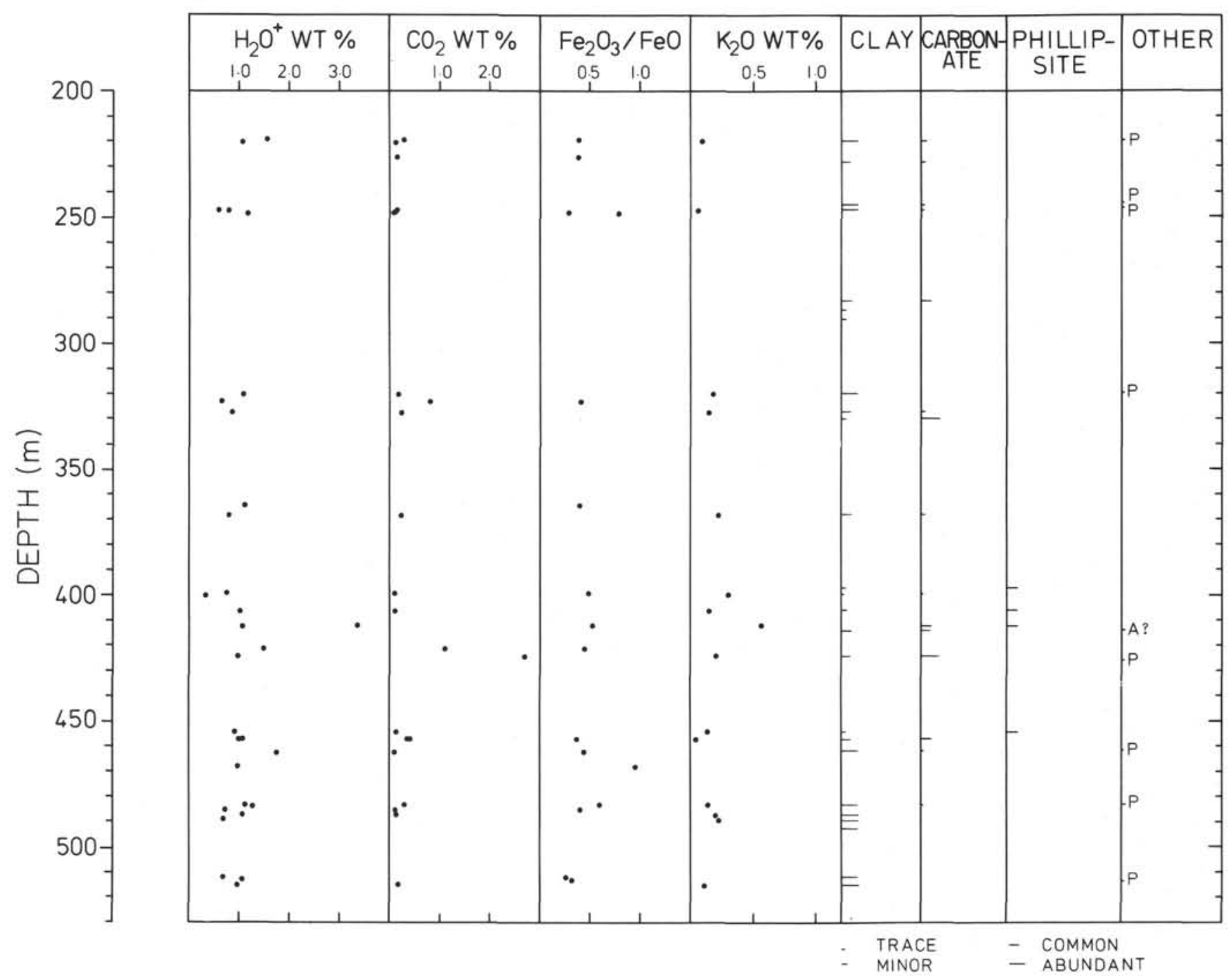

Figure 1c. Downhole variations in $\mathrm{H}_{2} \mathrm{O}^{+}, \mathrm{CO}_{2}, \mathrm{~K}_{2} \mathrm{O}, \mathrm{Fe}_{2} \mathrm{O}_{3} / \mathrm{FeO}$ ratios and various secondary minerals, Hole 333A. Figure includes shipboard chemical data and shore-based chemical and mineralogical data produced by us. Symbols are as follows: $P=$ pyrite, $A=$ analcime (?) $S=$ silica, $S u=$ sulfate mineral.

ent it lines the walls and predates the pyrite, whereas the carbonate and pyrite are normally intergrown with one another.

\section{Leucoxene}

Vesicles in a few basalts are lined with black, opaque material which is white in reflected light. In some vesicles it forms a rim or coating of uniform thickness on the vesicle wall; in others it fills irregular spaces. Most coatings have radial fractures suggestive of shrinkage cracks (Plate 2, Figure 4).

This material was identified optically as leucoxene, and microprobe analyses indicate a very high $\mathrm{TiO}_{2}$ content (Table 7). $\mathrm{SiO}_{2}$ and $\mathrm{Al}_{2} \mathrm{O}_{3}$ make up about 5 and 6 $\mathrm{wt} \%$, respectively, and oxide totals suggest about 25 wt $\% \mathrm{H}_{2} \mathrm{O}$. The origin of this material is not clear. It has been found only in vesicles, never in fractures or veinlets, suggesting an origin within the rock. Some vesicles are rimmed with glass containing abundant minute acicular opaque crystals, possibly ilmenite, and alteration of this material might provide a source of $\mathrm{TiO}_{2}$. In any case, the occurrence of leucoxene in the vesicles indicates that $\mathrm{TiO}_{2}$ distribution in these basalts is not entirely unaffected by secondary processes.

\section{Manganese Coatings}

Black, opaque material with a distinct botryoidal habit is common in clay-lined vesicles and carbonate veins. In vesicles it forms a discontinuous coating on yellow smectite surrounding an open central cavity (Plate 2, Figure 5). In veins it occurs as small scattered specks intergrown with calcite.

Microprobe analyses of this material indicate that it consists chiefly of $\mathrm{MnO}$ with small quantities of $\mathrm{Al}_{2} \mathrm{O}_{3}$, $\mathrm{Na}_{2} \mathrm{O}, \mathrm{CaO}, \mathrm{MgO}, \mathrm{FeO}^{*}$, and $\mathrm{K}_{2} \mathrm{O}$ (Table 7). Oxide totals suggest about 45 to $50 \mathrm{wt} \% \mathrm{H}_{2} \mathrm{O}$. The manganese coatings occur only in fractures and veins or in vesicles 
SITE 334

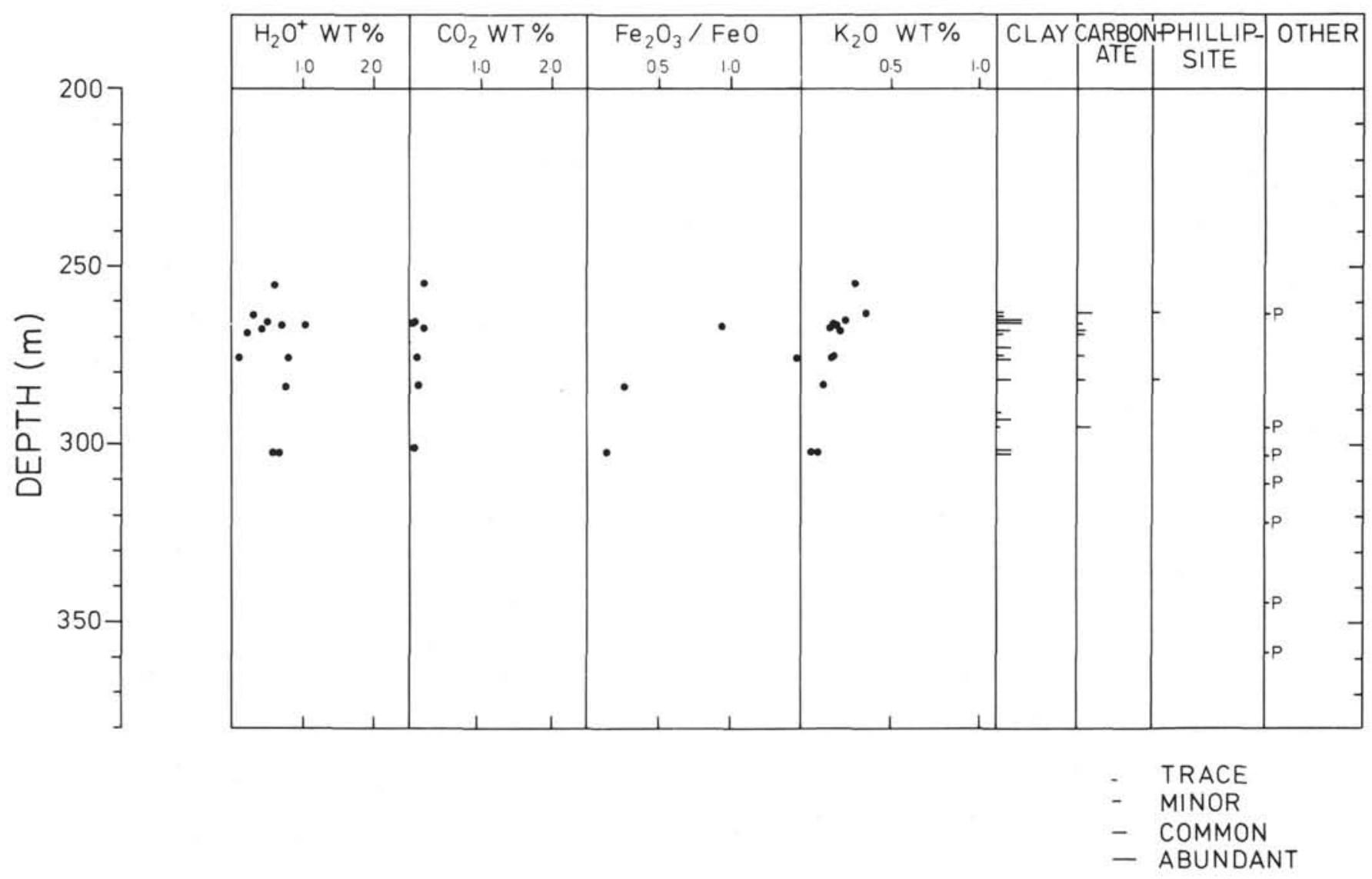

Figure 1d. Downhole variations in $\mathrm{H}_{2} \mathrm{O}^{+}, \mathrm{CO}_{2}, \mathrm{~K}_{2} \mathrm{O}, \mathrm{Fe}_{2} \mathrm{O}_{3} / \mathrm{FeO}$ ratios and various secondary minerals, Site 334. Figure includes shipboard chemical data and shore-based chemical and mineralogical data produced by us. Symbols are as follows: $P=$ pyrite, $A$ = analcime (?), $S=$ silica, $S u=$ sulfate mineral .

located in oxidation halos around fractures suggesting introduction of $\mathrm{MnO}$ into the rock from seawater.

\section{Iron Hydroxides}

Red iron oxides, identified optically as hematite, are widespread in small quantities in Leg 37 basalts. They occur primarily as thin coatings or stains along fractures and vesicle walls in oxidation halos. Most of the hematite appears to have been formed by breakdown of olivine. Small isolated masses of hematite sometimes occur on vesicle walls where they are coated with smectite (Plate 2, Figure 6). These may have formed directly or by alteration of an earlier phase such as a sulfide. Analyzed material consists chiefly of iron with small amounts of $\mathrm{SiO}_{2}, \mathrm{Al}_{2} \mathrm{O}_{3}, \mathrm{MgO}$, and $\mathrm{CaO}$ (Table 7).

\section{Sulfate Minerals}

Sulfates are common in the upper parts of Holes $332 \mathrm{~A}$ and 332B where they occur in smectite-lined vesicles often associated with calcite (Plate 1, Figure 2). These minerals form white, acicular to prismatic crystals with high negative relief and very low birefringence. The crystals grow in radial clusters (Plate 1, Figure 3 ) or in random orientation in the vesicles.
The crystal form and optical properties of this mineral are similar to pickeringite (Bandy, 1938), and microprobe analyses confirm that it is a magnesium-aluminum sulfate. However, the mineral burns readily under the electron beam, even when defocused, and the analyses reported in Table 6 probably reflects significant loss of $\mathrm{SO}_{3}$ and perhaps $\mathrm{H}_{2} \mathrm{O}$. X-ray diffraction patterns have not yet been obtained.

The smectite associated with these minerals is invariably the brown, high- $\mathrm{MgO}$ variety, and the occurrence of sulfates is unrelated to oxidation halos. In Hole 332B pyrite framboids are present in nearby vesicles, but no relationship between the two minerals has been established.

\section{Silica Minerals}

Opal is the only silica mineral definitely identified in Leg 37 basalts, and it occurs only in the highly altered olivine-phyric basalts of Hole 332B. Here it replaces olivine phenocrysts along with carbonate and minor amounts of smectite. The opal is colorless with a high negative relief and is isotropic. It was initially identified as analcime, but microprobe analyses indicate that it is nearly pure $\mathrm{SiO}_{2}$ with very minor amounts of $\mathrm{Al}_{2} \mathrm{O}_{3}$ and $\mathrm{FeO}$ and with about $3.5 \mathrm{wt} \% \mathrm{H}_{2} \mathrm{O}$. 
SITE 335

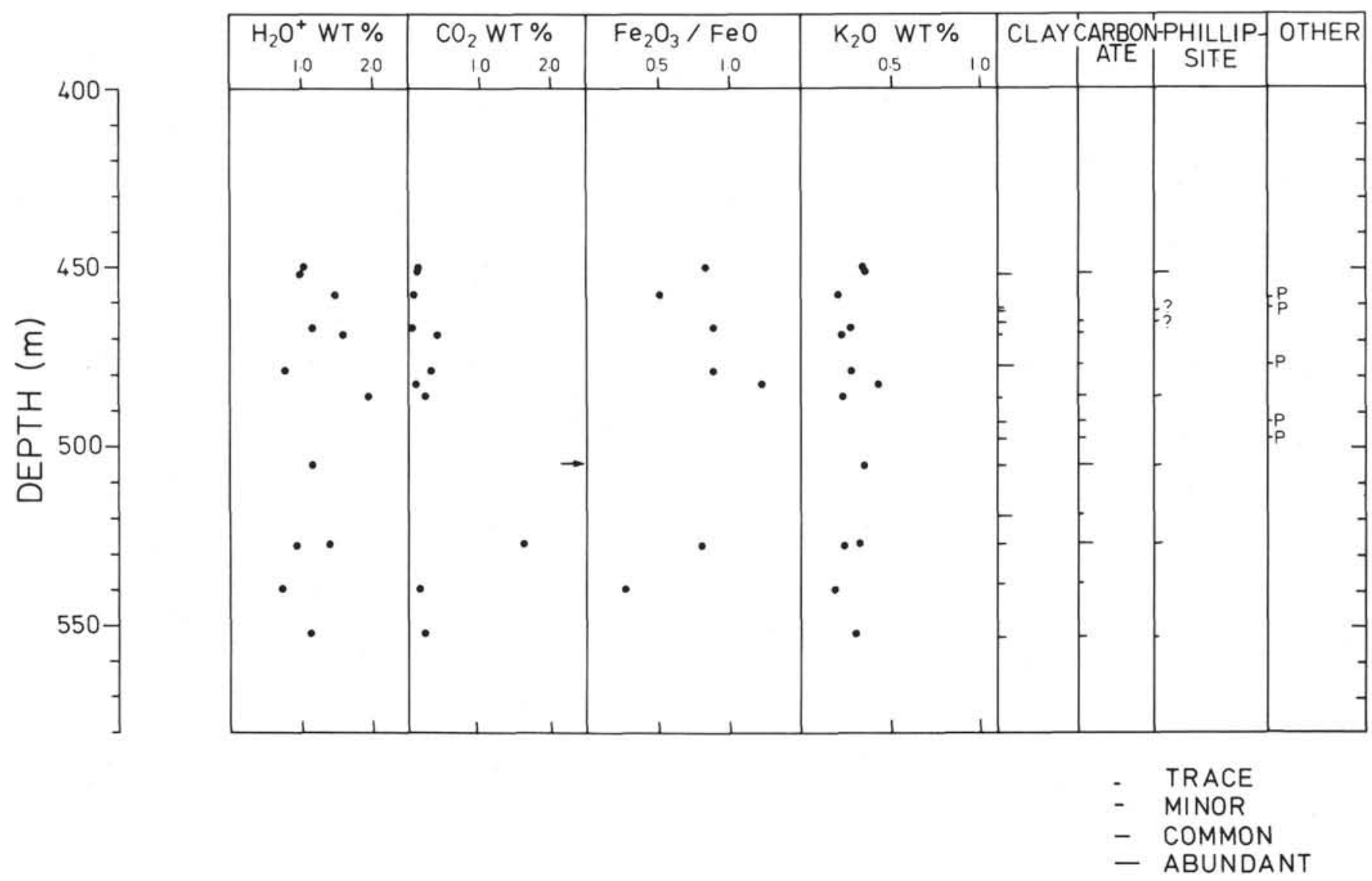

Figure 1e. Downhole variations in $\mathrm{H}_{2} \mathrm{O}^{+}, \mathrm{CO}_{2}, \mathrm{~K}_{2} \mathrm{O}, \mathrm{Fe}_{2} \mathrm{O}_{3} / \mathrm{FeO}$ ratios and various secondary minerals, Site 335. Figure includes shipboard chemical data and shore-based chemical and mineralogical data produced by us. Symbols are as follows: $P=$ pyrite, $A=$ analcime (?), $S=$ silica, $S u=$ sulfate mineral.

\section{Paragenesis of Secondary Minerals}

Most vesicle and vein fillings reflect a consistent order of formation of secondary minerals. Smectites are almost invariably the first to form, followed by phillipsite, carbonate, or pyrite. Brown or pale green smectite usually predates the yellow or red varieties suggesting smectite deposition under conditions of increasing oxidation. In a few vesicles this order is reversed probably as a result of later oxidizing fluids penetrating between the vesicle wall and the preexisting brown smectite (Plate 1, Figure 1).

Phillipsite and calcite usually occur together with the zeolite lining the walls of fractures and veinlets. The central part of the vein is normally filled with calcite, either by itself or intergrown with randomly oriented phillipsite crystals. In one specimen (332B-23-1, 78-80 $\mathrm{cm})$ the central cavity is filled with yellow smectite (Plate 2, Figure 2).

Pyrite and other opaque minerals usually follow smectite and are often associated with calcite. Pyrite is found only with green smectite whereas manganese coatings occur only with yellow smectites. Hematite is normally later than smectite, but in a few specimens the order is reversed (Plate 2, Figure 6).
Sulfate minerals fill vesicles lined with brown smectite and are often intergrown with calcite. Where aragonite and magnesian-iron carbonates are present, they usually are later than calcite.

\section{CHEMICAL CHANGES ASSOCIATED WITH LOW TEMPERATURE ALTERATION}

Comparison of fresh and altered basalts from the same lithologic unit reveals that in general $\mathrm{H}_{2} \mathrm{O}^{+}, \mathrm{CO}_{2}$, $\mathrm{K}_{2} \mathrm{O}$, and $\mathrm{Fe}_{2} \mathrm{O}_{3} / \mathrm{FeO}$ ratios increase with increasing alteration. However, variations in these parameters, as well as in other oxides, are nonsystematic and depend more on the presence or absence of specific secondary minerals than on the overall intensity of alteration.

$\mathrm{CO}_{2}$ contents reflect carbonate fixation in the form of calcite, aragonite, dolomite, or magnesite. This results in significant increases in whole-rock values of $\mathrm{CaO}$, $\mathrm{MgO}$, or $\mathrm{FeO}$, depending on which mineral is present. Secondary increases in $\mathrm{MgO}$ and $\mathrm{FeO}$ are most pronounced in the carbonate-rich zone in Hole 332B (Figure 1b); elsewhere carbonate fixation leads to increases chiefly in $\mathrm{CaO}$. Interestingly enough, $\mathrm{CO}_{2}$ values show little correlation with either $\mathrm{H}_{2} \mathrm{O}^{+}$or $\mathrm{Fe}_{2} \mathrm{O}_{3} / \mathrm{FeO}$ ratios (Figure 1a-e) despite the fact that 
TABLE 4

Defocused Microprobe Analyses of Carbonate Minerals

\begin{tabular}{lrrrrrr}
\hline & 1 & 2 & 3 & 4 & \multicolumn{1}{c}{5} & \multicolumn{1}{c}{6} \\
\hline $\mathrm{CaO}$ & 51.07 & 54.17 & 50.87 & 28.64 & \multicolumn{1}{c}{5.79} & \multicolumn{1}{c}{8.33} \\
$\mathrm{BaO}$ & 0.06 & - & 0.03 & - & - & - \\
$\mathrm{FeO} *$ & 0.30 & 0.05 & 0.01 & 0.32 & 14.49 & 34.71 \\
$\mathrm{MgO}$ & 4.02 & 0.04 & 2.82 & 21.00 & 29.11 & 11.17 \\
$\mathrm{MnO}$ & 0.11 & 0.01 & 0.02 & 0.14 & 0.15 & 0.52 \\
$\mathrm{CO}_{2}$ & 44.74 & 42.60 & 43.02 & 45.68 & 45.29 & 40.32
\end{tabular}

Note: $\mathrm{FeO}^{*}=$ total iron; $-=$ not detected; $1=$ Calcite associated with sulfate minerals in smectite-lined vesicles (332B-2-6, 94-97 $\mathrm{cm}) ; 2$ = Calcite filling smectite lined vesicle (332B-42-2, 26-28 $\mathrm{cm}) ; 3=$ Calcite in vesicle $(332 \mathrm{~B}-42-2,45-47 \mathrm{~cm}) ; 4=$ Dolomite in zoned sphere in vesicle (332B-35-3, 69-72); 5 = Calcium- and iron-rich magnesite in zoned sphere in vesicle (332B-33-1, 5-8 $\mathrm{cm}) ; 6$ = Calcium- and magnesium-rich siderite in zoned sphere in vesicle (332B-33-1, 5-8 cm).

TABLE 5

Compositional Variations Across a Single Carbonate Sphere from Core to Rim (332B-33-1, 5-8 cm)

\begin{tabular}{lrrrr}
\hline & Core & & & Rim \\
\hline $\mathrm{CaO}$ & 5.44 & 7.17 & 19.11 & 8.67 \\
$\mathrm{BaO}$ & - & - & 0.06 & 0.09 \\
$\mathrm{MgO}$ & 27.22 & 26.20 & 7.72 & 18.58 \\
$\mathrm{FeO}$ & 15.83 & 15.00 & 27.67 & 24.07 \\
$\mathrm{MnO}$ & 0.22 & 0.22 & 0.50 & 0.32 \\
$\mathrm{CO}_{2}$ & 43.82 & 43.56 & 40.71 & 42.06 \\
\hline
\end{tabular}

Note: $\mathrm{FeO}^{*}=$ total iron; $-=$ not detected.

TABLE 6

Microprobe Analyses of Zeolite and Sulfate Minerals

\begin{tabular}{lrrrcc}
\hline & \multicolumn{1}{c}{1} & \multicolumn{1}{c}{2} & \multicolumn{1}{c}{3} & 4 & 5 \\
\hline $\mathrm{SiO}_{2}$ & 0.42 & 1.31 & 0.59 & 44.39 & 45.95 \\
$\mathrm{Al}_{2} \mathrm{O}_{3}$ & 29.29 & 23.22 & 16.88 & 22.19 & 22.57 \\
$\mathrm{CaO}$ & 0.04 & 0.06 & 0.03 & 5.21 & 5.03 \\
$\mathrm{Na}_{2} \mathrm{O}$ & 0.69 & 0.30 & 2.33 & 4.44 & 4.05 \\
$\mathrm{~K}_{2} \mathrm{O}$ & 0.01 & 0.02 & \multicolumn{1}{c}{ tr } & 4.71 & 4.51 \\
$\mathrm{MgO}$ & 36.20 & 33.50 & 24.59 & 0.03 & $\operatorname{tr}$ \\
$\mathrm{FeO}^{*}$ & 3.02 & 3.62 & 2.00 & - & - \\
$\mathrm{MnO}$ & 0.02 & - & 0.06 & 0.07 & - \\
$\mathrm{TiO}_{2}$ & - & 0.01 & $\operatorname{tr}$ & - & 0.01 \\
$\mathrm{P}_{2} \mathrm{O}_{5}$ & 0.25 & 0.52 & - & - & - \\
$\mathrm{SO}_{3}$ & 15.30 & 8.76 & 15.94 & - & - \\
$\mathrm{BaO}_{\mathrm{Total}}$ & 0.64 & 0.04 & 0.18 & - & - \\
\hline
\end{tabular}

Note: $\mathrm{FeO}^{*}=$ total iron; $\operatorname{tr}=\operatorname{trace} ;-=$ not detected; $1=$ Sulfate mineral in smectite-lined vesicle (332B-2-6, $90-93 \mathrm{~cm}) ; 2$ = Sulfate mineral in smectite-lined vesicle (332B-2-6, 90-93 cm); 3 = Sulfate mineral in smectitelined vesicle $(332 \mathrm{~B}-2-6,90-93 \mathrm{~cm}) ; 4=$ Phillipsite in smectite-lined vein $(332 \mathrm{~B}-43-2,55-57 \mathrm{~cm}) ; 5=$ Phillipsite in vein $(332 \mathrm{~B}-42-2,45-47 \mathrm{~cm})$.

most of the carbonate was introduced along open channelways. For example, $\mathrm{H}_{2} \mathrm{O}^{+}$and $\mathrm{Fe}_{2} \mathrm{O}_{3} / \mathrm{FeO}$ ratios in the extraordinarily carbonate-rich zone in Hole 332B are similar to values in the rocks above and below this interval (Figure 1b).
TABLE 7

Microprobe Analyses of Opaque Minerals

\begin{tabular}{|c|c|c|c|}
\hline & 1 & 2 & 3 \\
\hline $\mathrm{SiO}_{2}$ & 4.64 & 0.22 & 8.94 \\
\hline $\mathrm{TiO}_{2}$ & 61.85 & 0.02 & - \\
\hline $\mathrm{Al}_{2} \mathrm{O}_{3}$ & 6.29 & 2.20 & 2.28 \\
\hline $\mathrm{FeO}^{*}$ & 0.04 & 0.53 & 62.45 \\
\hline $\mathrm{MnO}$ & - & 46.88 & 0.37 \\
\hline $\mathrm{MgO}$ & 0.06 & 0.62 & 2.09 \\
\hline $\mathrm{CaO}$ & 0.08 & 1.05 & 1.93 \\
\hline $\mathrm{Na}_{2} \mathrm{O}$ & 0.33 & 1.25 & - \\
\hline $\mathrm{K}_{2} \mathrm{O}$ & 0.04 & 0.45 & 0.02 \\
\hline $\mathrm{ZnO}$ & 0.04 & 0.04 & - \\
\hline $\mathrm{Cl}$ & 0.11 & 0.13 & 0.03 \\
\hline
\end{tabular}

Note: $\mathrm{FeO}^{*}=$ total iron; $-=$ not detected; 1 = Leucoxene lining vesicle $(332 \mathrm{~B}-8-1,12 \mathrm{~cm}) ; 2=$ Manganese coating in smectitelined vesicle $(332 \mathrm{~B}-6-2,122 \mathrm{~cm})$; $3=$ Red opaque grain on vesicle wall $(332 \mathrm{~B}-42-2,26-28 \mathrm{~cm})$.

$\mathrm{H}_{2} \mathrm{O}^{+}$and $\mathrm{K}_{2} \mathrm{O}$ variations reflect chiefly variations in the modal abundance of smectite and, to a lesser degree, of phillipsite (Figure 1a-e). However, $\mathrm{H}_{2} \mathrm{O}^{+}$and $\mathrm{K}_{2} \mathrm{O}$ contents in altered rocks are strongly dependent on which smectite variety is present. Growth of brown smectite results in large increases in $\mathrm{H}_{2} \mathrm{O}^{+}$with little or no increase in $\mathrm{K}_{2} \mathrm{O}$. Where this occurs as in Hole 332B, there is a marked lack of correlation between $\mathrm{H}_{2} \mathrm{O}^{+}$and $\mathrm{K}_{2} \mathrm{O}$ (Figure 2b); where yellow smectite predominates as in Hole $332 \mathrm{~A}, \mathrm{~K}_{2} \mathrm{O}$ and $\mathrm{H}_{2} \mathrm{O}^{+}$show a good positive correlation (Figure 2a).

$\mathrm{Fe}_{2} \mathrm{O}_{3} / \mathrm{FeO}$ ratios in altered rocks are generally between 0.50 and 0.75 with a few values greater than 1 (Figure 1a-e). The higher ratios are generally found in alteration halos around open channelways, reflecting introduction of oxidizing fluids into the rock. $\mathrm{Fe}_{2} \mathrm{O}_{3} / \mathrm{FeO}$ ratios generally show a good correlation with $\mathrm{K}_{2} \mathrm{O}$ (Figure $3 \mathrm{a}$, b) because yellow, $\mathrm{K}_{2} \mathrm{O}$-rich smectite is abundant in the oxidation halos. In Hole $332 \mathrm{~A}$ there is a fair correlation between $\mathrm{Fe}_{2} \mathrm{O}_{3} / \mathrm{FeO}$ ratios and $\mathrm{H}_{2} \mathrm{O}^{+}$but no such pattern is discernible in Hole 332B (Figure 4b). This is in part due to the fact that reducing conditions prevailed in many fractures in the lower part of Hole 332B where pyrite and green smectite are abundant.

$\mathrm{SiO}_{2}$ values are quite variable within any given lithologic unit, generally decreasing slightly with increasing alteration. However, where alteration has resulted in the precipitation of opal, as in Hole 332B, significant increases in $\mathrm{SiO}_{2}$ occur.

$\mathrm{TiO}_{2}$ and $\mathrm{P}_{2} \mathrm{O}_{3}$ values are quite uniform within a given lithologic unit and are little affected by alteration. However, the presence of secondary leucoxene in a few specimens indicates that $\mathrm{TiO}_{2}$ is not completely immobile during alteration. There is no evidence, however, that $\mathrm{TiO}_{2}$ was introduced into the rocks from seawater.

$\mathrm{Al}_{2} \mathrm{O}_{3}$ is also little affected by low temperature alteration. Primary alumina-bearing minerals are rarely 

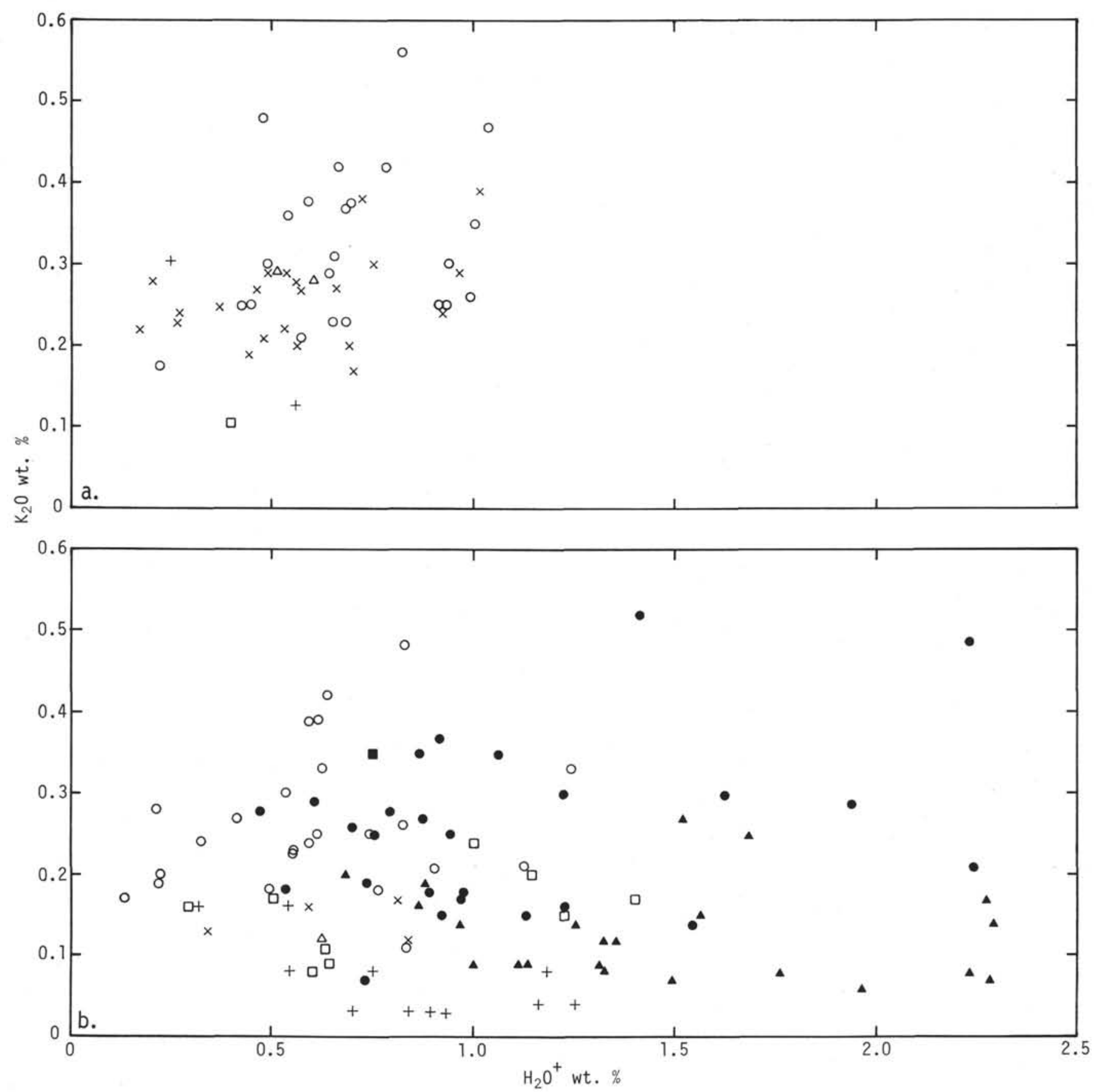

Figure 2. Variation of $\mathrm{K}_{2} \mathrm{O}$ with $\mathrm{H}_{2} \mathrm{O}^{+}$at Site 332. (a) Hole 332A. Figures include shipboard chemical data and chemical analyses by us. Analyses are identified by primary magma group (see Flower et al., this volume) in order to account for variations related to magma chemistry rather than to secondary processes. Magma groups are identified as follows for each hole:

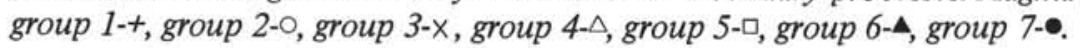

decomposed and the alumina-bearing secondary minerals, chiefly smectite and phillipsite, have $\mathrm{Al}_{2} \mathrm{O}_{3}$ values lower than or similar to the whole-rock values.

Manganese has been introduced into some rocks along open channelways but whole rock values of $\mathrm{MnO}$ appear to be unaffected by this process.

\section{DOWNHOLE VARIATIONS IN ALTERATION INTENSITY}

Downhole variations in $\mathrm{H}_{2} \mathrm{O}^{+}, \mathrm{CO}_{2}, \mathrm{~K}_{2} \mathrm{O}, \mathrm{Fe}_{2} \mathrm{O}_{3}$ / $\mathrm{FeO}$ ratios and abundance of secondary minerals are shown in Figure 1a-e. Included are data from shipboard studies and from specimens analyzed by us (Chapters 2, 3, 4, and 5, this volume). The shipboard data are somewhat biased because they generally represent the freshest material available from a given interval. Hole $332 \mathrm{~B}$ is the most useful for investigating downhole variations because of the abundance of chemical and mineralogical data and the great depth of penetration ( $583 \mathrm{~m}$ subbasement).

It is apparent from these figures that there are no systematic downhole variations in character or intensi- 

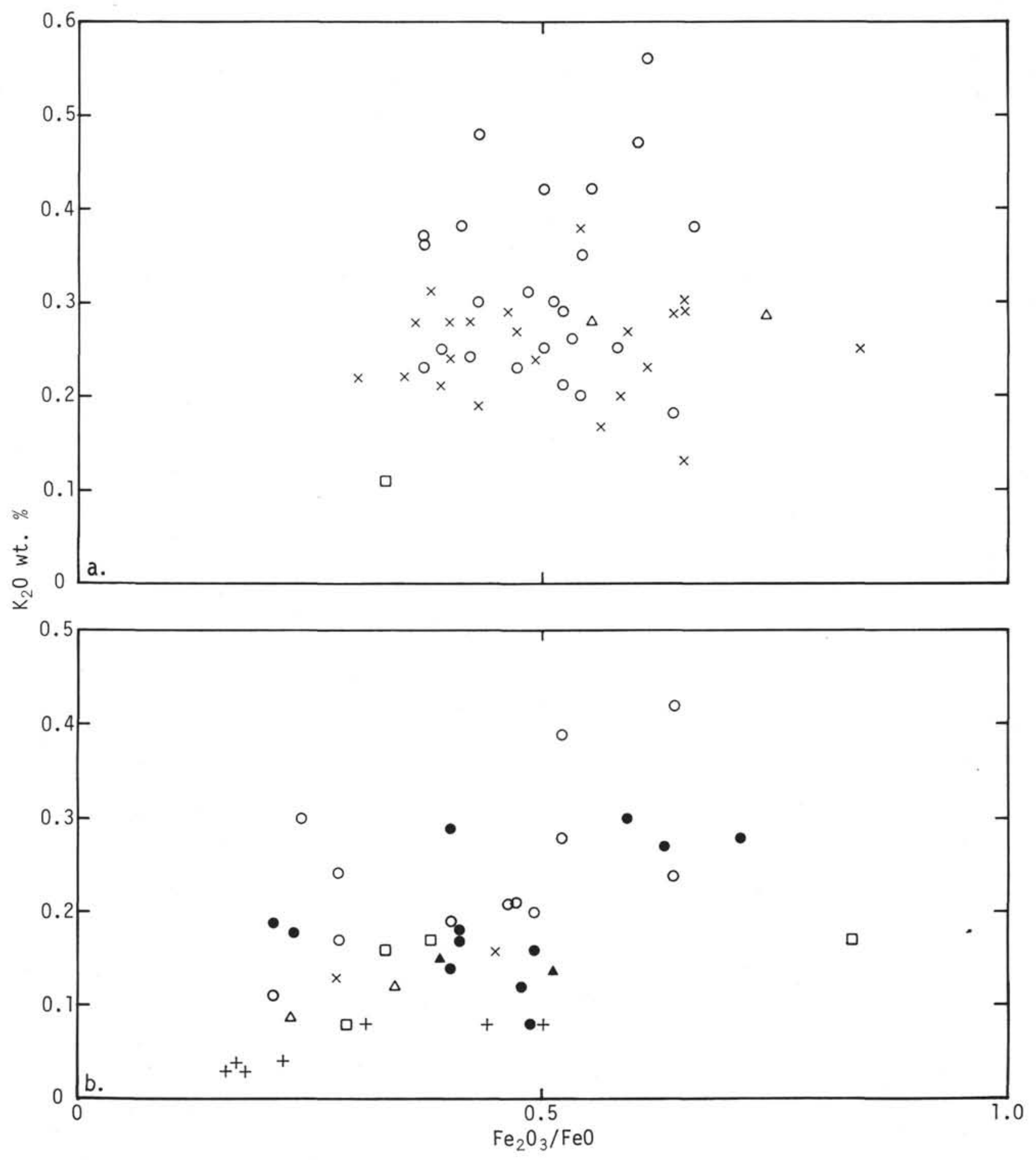

Figure 3. Variation of $\mathrm{K}_{2} \mathrm{O}$ with $\mathrm{Fe}_{2} \mathrm{O}_{3} / \mathrm{FeO}$ ratio at Site 332. (a) Hole 332A, (b) Hole 332B. Figures do not contain shipboard chemical data because $\mathrm{Fe}_{2} \mathrm{O}_{3} / \mathrm{FeO}$ ratios were not determined. Magma groups are the same as for Figure 2.

ty of alteration. Hole $332 \mathrm{~A}$ penetrated the freshest rocks. Here $\mathrm{H}_{2} \mathrm{O}^{+}$is typically less than $1 \mathrm{wt} \%, \mathrm{CO}_{2}$ is very low, except in a few specimens cut by carbonate veinlets, and $\mathrm{Fe}_{2} \mathrm{O}_{3} / \mathrm{FeO}$ ratios average about 0.5 . $\mathrm{K}_{2} \mathrm{O}$ contents are variable in the upper part of the sequence, but become more uniform in the lower part. The average $\mathrm{K}_{2} \mathrm{O}$ content decreases slightly with depth, ranging from about $0.4 \mathrm{wt} \%$ at the top of the hole to about $0.2 \mathrm{wt} \%$ at the bottom.
The basalts of Hole 332B are considerably more altered than those of Hole $332 \mathrm{~A}$ but consistent downhole trends are again lacking. $\mathrm{H}_{2} \mathrm{O}$ values are quite variable with a slight downhole increase in the average. Maximum values occur in the interval from 600 to 680 meters subbottom. Below 680 meters values are all less than $1 \mathrm{wt} \%$, similar to those at the top of the hole. $\mathrm{CO}_{2}$ contents are relatively low except in the extraordinarily carbonate-rich interval between 510 and 


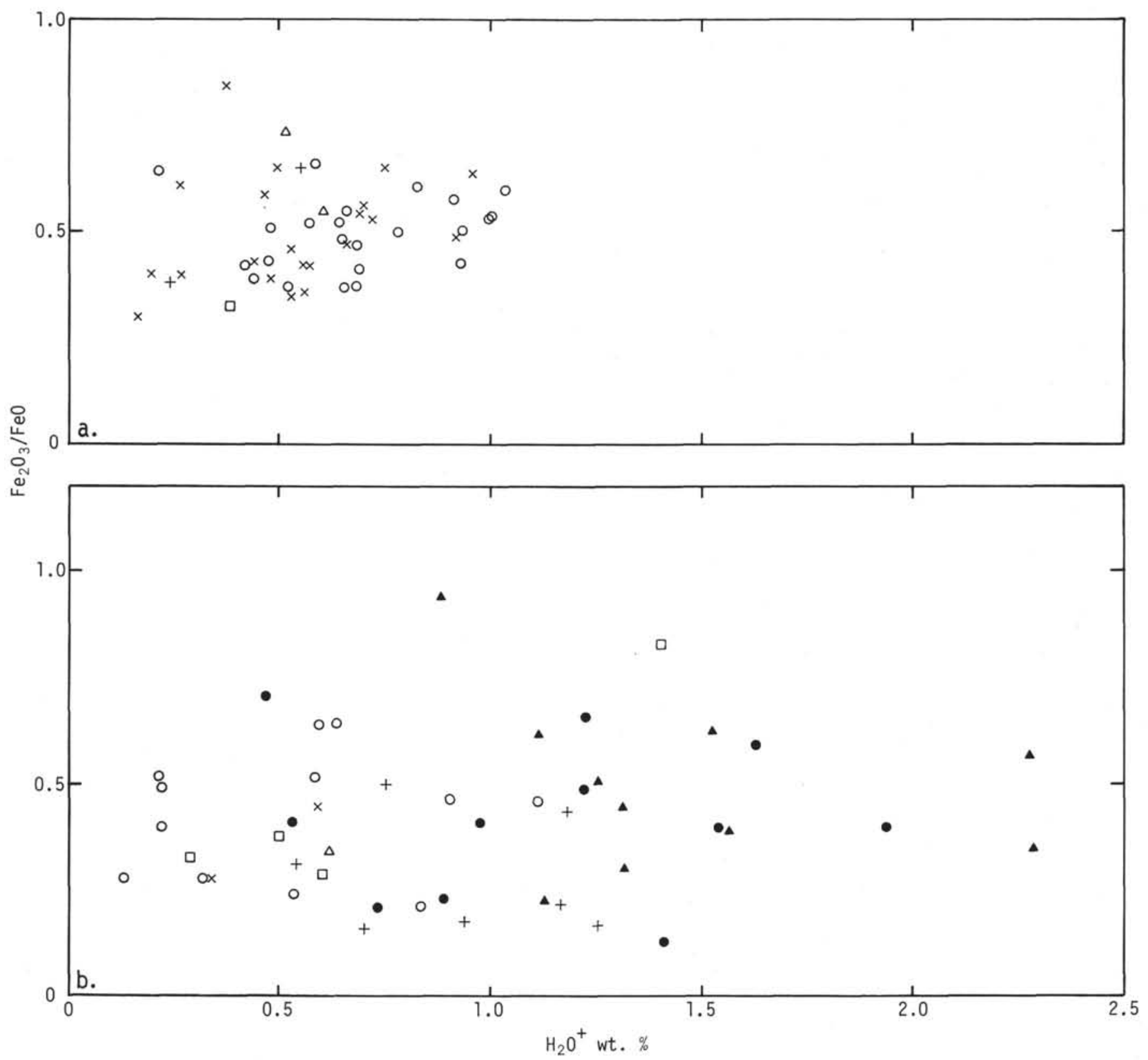

Figure 4. Variation of $\mathrm{Fe}_{2} \mathrm{O}_{3} / \mathrm{FeO}$ ratio with $\mathrm{H}_{2} \mathrm{O}^{+}$at Site 332. (a) Hole $332 \mathrm{~A}$, (b) Hole 332B. Figures do not include shipboard chemical data because $\mathrm{Fe}_{2} \mathrm{O}_{3} / \mathrm{FeO}$ ratios were not determined. Magma groups are the same as for Figure 2.

600 meters subbottom. Here $\mathrm{CO}_{2}$ ranges up to nearly 7 wt\% reflecting the fixation of abundant magnesian-iron carbonate. $\mathrm{Fe}_{2} \mathrm{O}_{3} / \mathrm{FeO}$ ratios and $\mathrm{K}_{2} \mathrm{O}$ contents are somewhat higher than in Hole $332 \mathrm{~A}$. Both are highly variable over short distances, but again downhole trends are lacking.

Data are sparse for the other three major holes. The rocks at Site 335 have slightly higher average values of $\mathrm{H}_{2} \mathrm{O}, \mathrm{K}_{2} \mathrm{O}$, and $\mathrm{Fe}_{2} \mathrm{O}_{3} / \mathrm{FeO}$ ratios than those at other sites, perhaps reflecting their greater age. Individual values, however, are no greater than those found in other holes.

It is also apparent from Figure 1a-e that there is no consistent relationship between lithologic unit and the intensity or type of alteration. The carbonate-rich inter- val in Hole 332B corresponds quite closely to lithologic units 6 and 7, but elsewhere variations within lithologic units are generally greater than those between units. The boundary between lithologic units 1 and 2 in Hole $332 \mathrm{~B}$ is marked by a significant increase in $\mathrm{K}_{2} \mathrm{O}$ content, but other parameters show little change (Figure 1b). This $\mathrm{K}_{2} \mathrm{O}$ increase is also apparent in fresh specimens and probably reflects variations in initial magma chemistry.

Mitchell and Aumento (this volume) find an abrupt increase in $U$ at 465 meters subbottom depth in Hole 332B corresponding to the top of lithologic unit 5. The rocks at the top of this unit are visibly altered and have higher than normal $\mathrm{H}_{2} \mathrm{O}^{+}, \mathrm{CO}_{2}$, and $\mathrm{K}_{2} \mathrm{O}$. The alteration here could reflect either longer than normal ex- 
posure of the rocks on the sea floor or increased permeability along the contact.

\section{CONCLUSIONS}

Two main types of alteration are present in Leg 37 basalts. The earliest type, observed mainly in Holes 332B and 333A, involved formation of abundant brown smectite and minor carbonate in vesicles and groundmass interstices. This type of nonoxidative alteration produces significant increases in whole-rock $\mathrm{H}_{2} \mathrm{O}^{+}$ without notable changes in $\mathrm{K}_{2} \mathrm{O}, \mathrm{CO}_{2}$, or $\mathrm{Fe}_{2} \mathrm{O}_{3} / \mathrm{FeO}$ ratios.

The second type of alteration, often superimposed on the first, involved oxidation and hydration along fractures, veinlets, and other open channelways. Altered rocks are visibly discolored and contain abundant yellow or red smectite, carbonate, and phillipsite in the channelways and in adjacent alteration halos. This type of alteration clearly reflects interaction of seawater and rock along open channelways, resulting in whole-rock increases in $\mathrm{H}_{2} \mathrm{O}, \mathrm{K}_{2} \mathrm{O}, \mathrm{Fe}_{2} \mathrm{O}_{3} / \mathrm{FeO}$ ratios and usually $\mathrm{CO}_{2}$. Alteration halos are commonly 10 to 20 times the width of the associated channelway. Hence, when the rock is closely fractured, this type of alteration is pervasive; elsewhere, the altered and unaltered rocks are separated by sharp boundaries resulting in rapid downhole variations in the type and intensity of alteration.

Some veinlets in the lower part of Hole 332B contain abundant pyrite and green smectite indicating that not all fluids were oxidizing in character. The source of these fluids is unknown and it is possible that they were hydrothermal in origin. However, there is no evidence in the core of elevated temperatures.

A wide variety of secondary minerals is present in the altered basalts. These line or fill open vesicles, vugs, and fractures or replace interstitial groundmass material. Except for olivine, primary minerals are rarely affected by alteration. A few plagioclase phenocrysts exhibit minor replacement by calcite and phillipsite along cleavage traces, but most are fresh. No alteration of clinopyroxene was observed.

Chemical changes associated with alteration of Leg 37 basalts are nonsystematic and reflect the growth of specific secondary minerals rather than the intensity of alteration. Pervasive development of brown smectite results in little change in bulk chemistry except for increases in $\mathrm{H}_{2} \mathrm{O}^{+}$and concomitant decreases in other oxides. More localized oxidative alteration along open channelways results in notable increases in $\mathrm{H}_{2} \mathrm{O}^{+}, \mathrm{K}_{2} \mathrm{O}$, and $\mathrm{Fe}_{2} \mathrm{O}_{3} / \mathrm{FeO}$ ratios as a result of the growth of yellow or red smectite and phillipsite. Variations in $\mathrm{CO}_{2}, \mathrm{CaO}, \mathrm{MgO}$, and $\mathrm{FeO}$ can be correlated closely with the formation of various carbonate minerals. $\mathrm{SiO}_{2}$ generally decreases slightly with alteration except where opal has been precipitated. Whole-rock values of $\mathrm{Al}_{2} \mathrm{O}_{3}, \mathrm{TiO}_{2}$, and $\mathrm{P}_{2} \mathrm{O}_{5}$ are relatively unaffected by alteration. Redistribution of these oxides has occurred within altered rocks, but there is no evidence that they were introduced from outside sources.

No systematic variations were observed in the type or intensity of alteration with depth in layer 2 or with lithology. Downhole variations chiefly reflect differences in the spacing and abundance of fractures. This is true even in the carbonate-rich zone in Hole 332B which coincides with lithologic units 6 and 7 although the abundance of magnesian carbonates may be related to breakdown of olivine in these picritic basalts. Increased alteration was noted at the top of a few lithologic units reflecting either longer than normal exposure to the sea floor or increased permeability along the contact.

Within the time span represented by Leg 37 sites ( 3.5 to $\sim 13$ m.y.) there are no systematic variations in alteration with age. The basalts at the oldest site (Site 335) are macroscopically less altered than the youngest rocks drilled at Site 332. Sparse chemical data suggest that basalts ${ }^{2}$ at Site 335 have slightly higher average values of $\mathrm{H}_{2} \mathrm{O}$ and $\mathrm{K}_{2} \mathrm{O}$ than younger rocks; however, individual values are within the range of variation at younger sites.

\section{ACKNOWLEDGMENTS}

Thanks are due to G. Bullen and P. Watkins (Imperial College, London), H. Henning, P. van den Bogaard, R. Pier, and R.J. Starmer (Ruhr-Universität Bochum) for assistance with X-ray fluorescence and wet chemical analysis. A.A. Chodos (California Institute of Technology) provided valuable assistance with the microprobe analyses. P. Robinson gratefully acknowledges the support of the Alexander von Humboldt Stiftung (BRD) for the year 1974-1975. M.F.J. Flower, H.-U. Schmincke, and W. Ohnmacht were supported by Deutsche Forschungsgemeinschaft. P. Robinson thanks Prof. W. Schreyer for his interest and support during the author's stay at the Ruhr-Universität Bochum.

\section{REFERENCES}

Anderson, R.N., 1972. Petrologic significance of low heat flow on the flanks of slow-spreading mid-ocean ridges: Geol. Soc. Am. Bull., v. 83, p. 2947-2956.

Aumento, F., 1971. Uranium content of mid-ocean basalts: Earth Planet. Sci. Lett., v. 11, p. 90-94.

Bandy, M.C., 1938. Mineralogy of three sulphate deposits of northern Chile: Am. Mineral., v. 23, p. 669-760.

Hart, R., 1970. Chemical exchange between sea water and deep ocean basalts: Earth Planet. Sci. Lett., v. 9, p. 269279.

Love, L.G., 1964. Early diagenetic pyrite in fine-grained sediments and the genesis of sulphide ores. In Amstutz, G.C. (Ed.), Sedimentology and ore genesis, v. 2: Amsterdam (Elsevier).

Lister, C.R.B., 1972. On the thermal balance of a mid-ocean ridge: Geophys. J., v. 26, p. 515-535.

Melson, W.G., 1973. Basaltic glasses from the Deep Sea Drilling Project. Chemical characteristics, compositions of alteration products, and fission track "ages": EOS Am. Geophys. Union Trans., v. 54, p. 1011-1014.

Melson, W.G. and Thompson, G., 1973. Glassy abyssal basalts, Atlantic sea floor near St. Paul's Rocks: Petrography and composition of secondary clay minerals: Geol. Soc. Am. Bull., v. 84, p. 703-716.

Miyashiro, A.F., Shido, F., and Ewing, M., 1969. Diversity and origin of abyssal tholeiite from the Mid-Atlantic Ridge near $24^{\circ}$ and $30^{\circ}$ north latitude: Contrib. Mineral. Petrol., v. 23 , p. 38-52.

Scott, R.B. and Hajash, A., Jr., 1976. Initial submarine alteration of basaltic pillow lavas: A microprobe study: Am. J. Sci., v. 276 , p. $480-501$. 
Shido, F., Miyashiro, A.F., and Ewing, M., 1974. Compositional variations in pillow lavas from the Mid Atlantic Ridge: Marine Geol., v. 16, p. 177-190.
Tómassen, J. and Kristmannsdóttir, H., 1972. High temperature alteration minerals and thermal brines, Reykjanes, Iceland: Contrib. Mineral. Petrol., v. 36, p. 123-134. 
PLATE 1

Length of bar is $0.25 \mathrm{~mm}$.

Figure $1 \quad$ Vesicle filled with green smectite with outer layer of red smectite. Note concentric zoning in outer layer. Sample 332A-38-1, 144-146 cm.

Figure $2 \quad$ Vesicle rimmed with light brown smectite and partially filled with calcite. White acicular crystals are a magnesian-alumina sulfate. Note brown smectite replacing interstitial material in the groundmass. Sample 332B-2-6, $94-97 \mathrm{~cm}$.

Figure 3 Vesicle rimmed with light brown smectite and filled with radiating, acicular crystals of magnesian-alumina sulfate mineral. Sample 332B-2-6, 94-97 cm.

Figure $4 \quad$ Vesicle partly filled with hemispheres of calcite. Sample 332B-13-1, $72-74 \mathrm{~cm}$.

Figure $5 \quad$ Vesicle filled with spheres of iron-magnesian carbonate. Sample 332B-33-1, 5-8 cm.

Figure 6 Vug with outer coating of botryoidal calcite and inner layer of light brown iron-rich magnesite. Sample 332B-35-4, 58-65 cm. 
PLATE 1
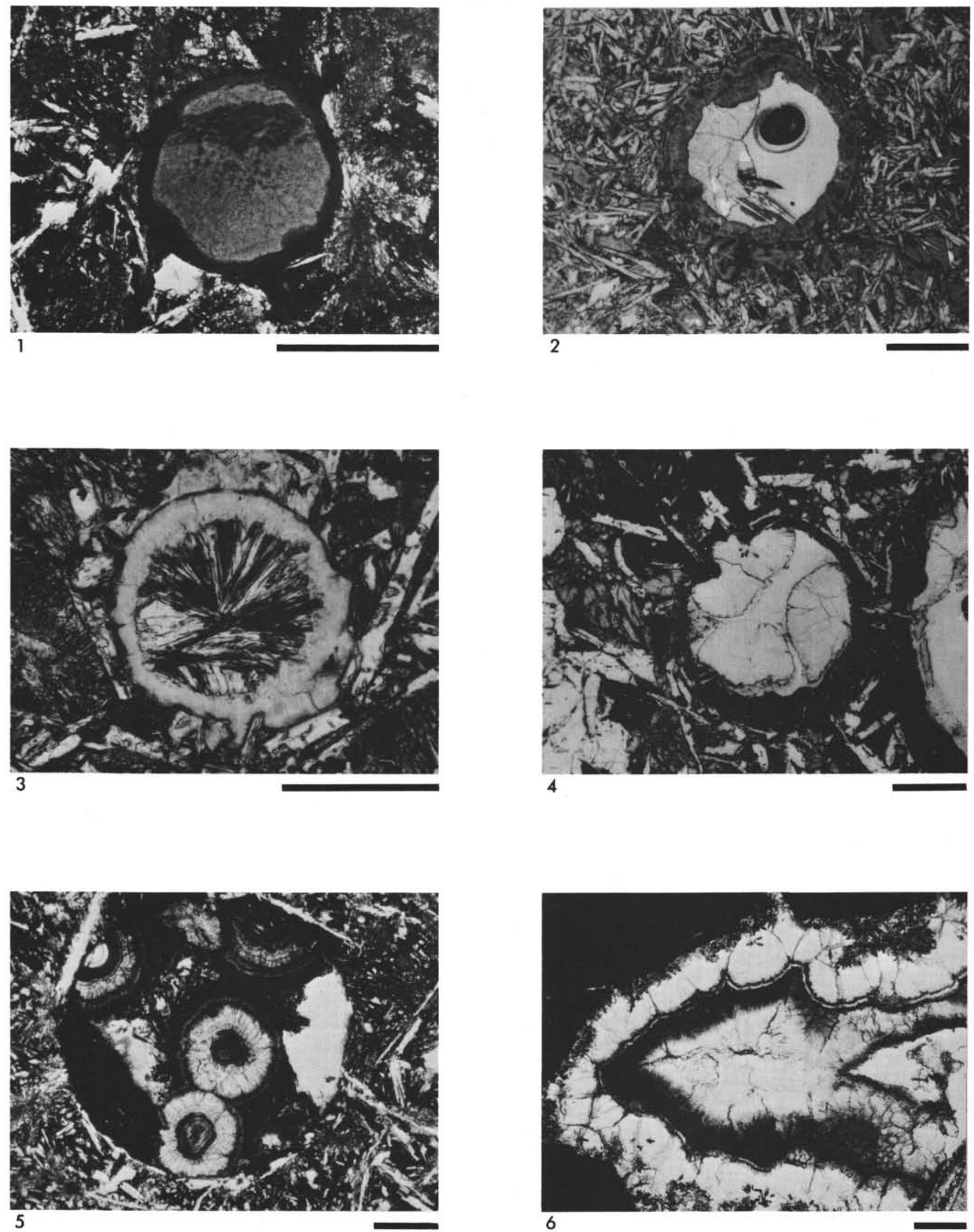


\section{PLATE 2}

Length of bar is $0.25 \mathrm{~mm}$.

Figure 1 Smectite-filled vesicle with pronounced color zoning. Narrow outer zone of pale yellow smectite grades into reddish-brown inner rim. This is followed by a somewhat thicker layer of pale yellow smectite again grading inward into a dark orangish-brown rim. The center of the vesicle is filled with colorless, relatively coarse-grained smectite. Sample 332B-42-2, $26-28 \mathrm{~cm}$.

Figure $2 \quad$ Veinlet lined with clusters of radiating phillipsite crystals and filled with yellow smectite. Sample 332B-23-1, 78-80 cm.

Figure 3 Coarsely crystalline phillipsite filling smectitelined vein. Sample 332B-42-2, 45-47 cm.

Figure 4 Vesicle rimmed with leucoxene. Note radial shrinkage cracks. Sample 332B-8-1, 12-14 cm.

Figure $5 \quad$ Vesicle partly filled with yellow smectite and opaque manganese crust. Sample 332B-6-2, 122$124 \mathrm{~cm}$.

Figure 6 Hematite grain on vesicle wall coated with reddish-yellow smectite. Center of vesicle is filled with calcite. Sample 332B-42-2, 26-28 cm. 
PLATE 2
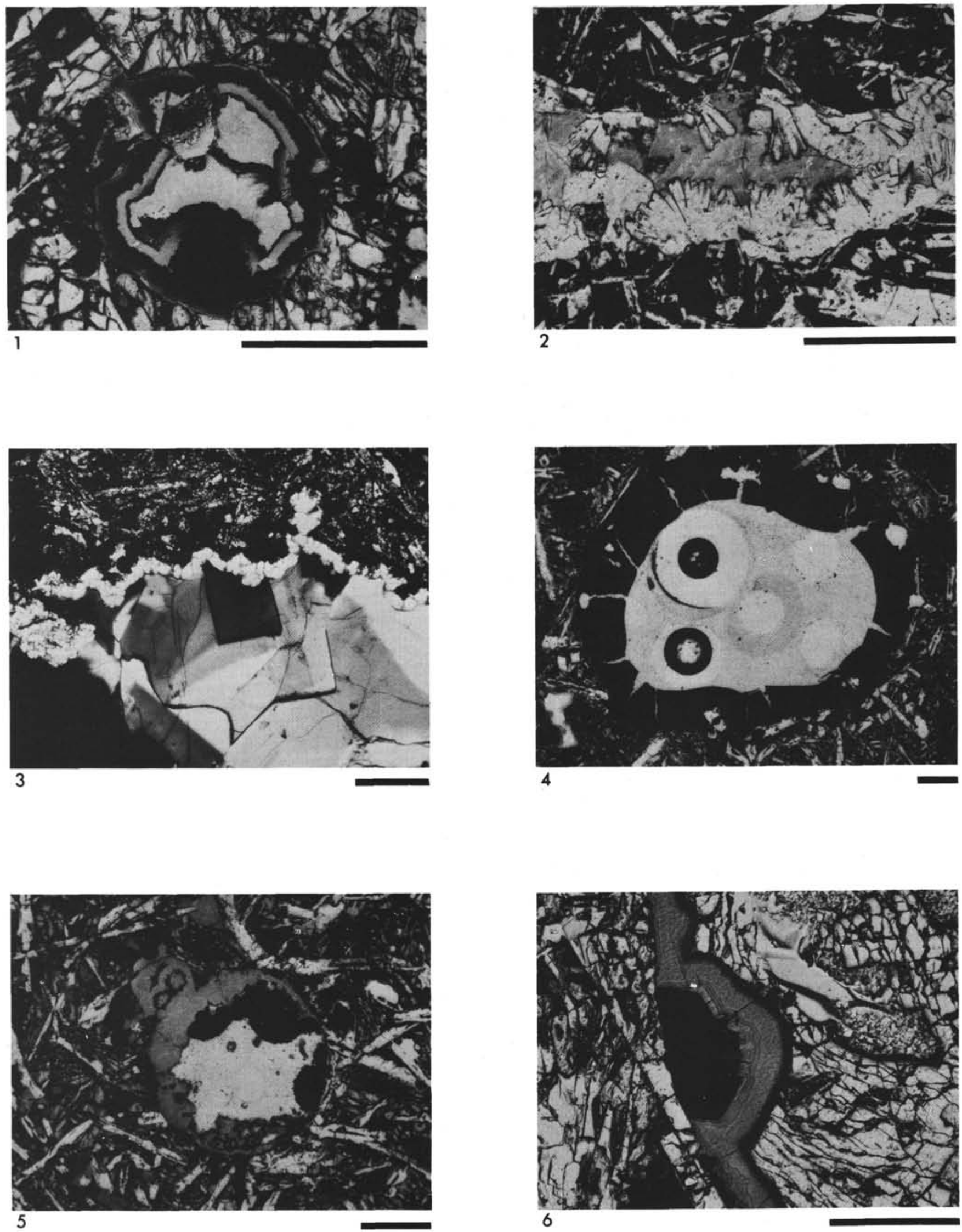